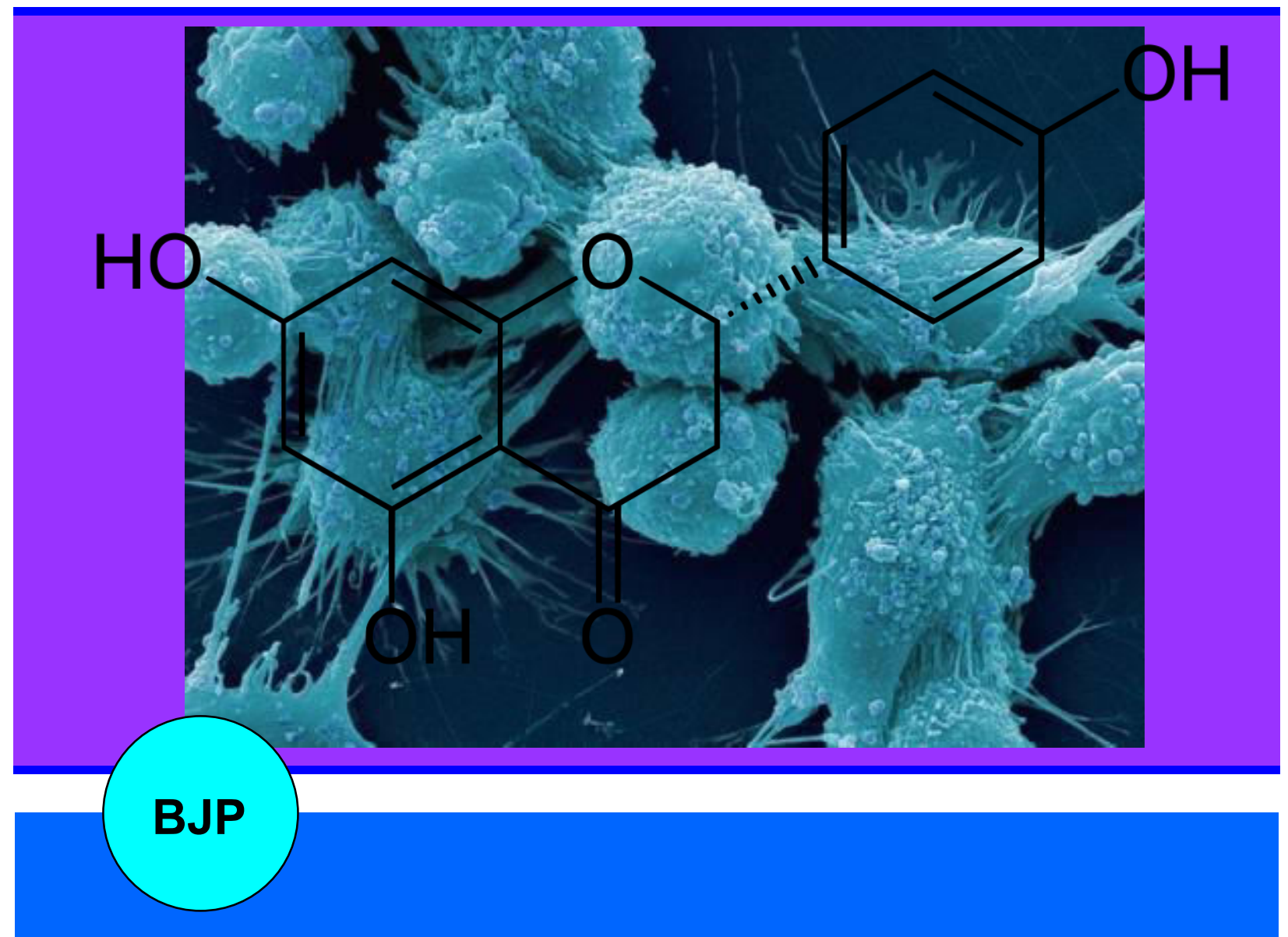

Bangladesh Journal of Pharmacology

Research Article

Naringenin modulates the metastasis of human prostate cancer cells by down regulating the matrix metalloproteinases -2 /-9 via ROS/ERK1/2 pathways 


\title{
Naringenin modulates the metastasis of human prostate cancer cells by down regulating the matrix metalloproteinases $-2 /-9$ via ROS/ERK1/2 pathways
}

\author{
Er Jiang Lin, Xian Zhang, Da Ya Wang, Shi Zhe Hong and Lei Yu Li \\ Department of Urology, Wenzhou Central Hospital, Wenzhou. Zhejiang 325 000, China.
}

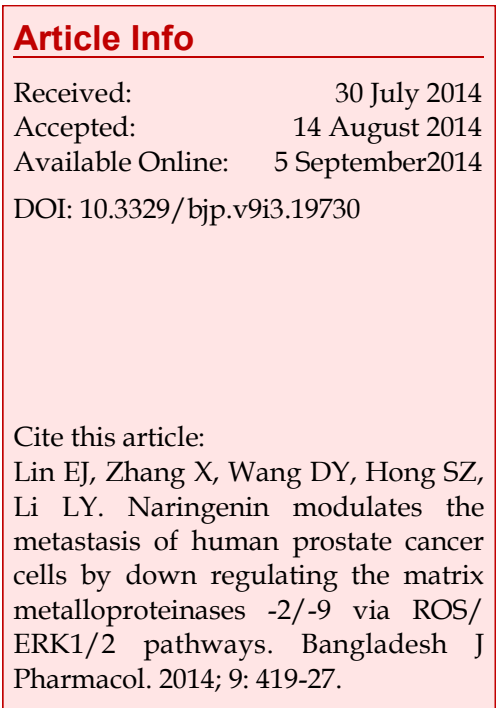

\begin{abstract}
Metastasis is a multifactorial condition that complicates cancer treatment options and widens the target of treatment. Matrix mettalopriteinases (MMPs) of the extracellular matrix (ECM) are involved in metastasis, thus they present as potential targets in halting cancer metastasis. The study was undertaken to investigate the influence of naringenin, a naturally occurring flavonoid on the metastasis of human prostate cancer cells (PC-3 and DU145). Naringenin was observed to be effective in reducing the viability and migratory percentage of PC-3 and DU145 cells. Naringenin significantly reduced the expression and activities of the chief MMPs (MMP-2 and -9) as assessed by Western blotting, real-time PCR and gelatin zymography analysis. The influence of naringenin on extracellular signal-regulated kinase (ERK) -ERK1/2 was analysed by Western blotting. The results indicated that naringenin was able to effectively inhibit ERK1/2. Naringenin exposure also significantly suppressed the levels of reactive oxygen species (ROS). Naringenin thus stands as an effective chemotherapeutic agent for prostate cancer treatment that could be further explored.
\end{abstract}

\section{Introduction}

Prostate cancer has been reported as the most common cancer in men accounting as the second most common cancer globally (Jemal et al., 2011). Treatment modalities comprise surgery, radiation and chemotherapy. Hormonal therapies have been found to be beneficial in early stages of hormone-responsive prostate cancer. Nevertheless as the tumour progresses to metastasis, it can turn castration resistant and fail responding to hormonal deprivation therapies (Amaral et al., 2012), resulting in few options for the treatment (Feldman and Feldman, 2001). The process of metastasis involves higher rate of proliferation, invasion, migration, and angiogenesis.

Metastasis requires degradation of the extracellular matrix (ECM) constituents via proteolytic enzymes (Simpson-Haidaris and Rybarczyk, 2001). Matrix metalloproteinases (MMPs), a family of endopeptidases majorly are involved in tumour cell migration, tissue invasion and metastasis (Itoh and Nagase, 2002). Over expression of MMPs has been reported as cancer progresses (Kilian et al., 2006; Mizutani et al., 2000; Gullu et al., 2000). Among the MMPs, MMP-2 and -9 are the key proteolytic enzymes that degrade type IV collagen and contribute to the course (Bernhard et al., 1994; EmmertBuck et al., 1994). MMP-2 and -9 also cleave type I collagen (Aimes and Quigley, 1995; Okada et al., 1992), the chief component in the stroma (Schor et al., 1980). The activation of MMP-2 and -9 has been reported to be associated with increasing tumour metastasis (Mook et al., 2004). Thus, inhibition of the MMP expression and/ 
or inhibition of the activities of the MMP enzymes could be contemplated as targets for preventing cancer metastasis (Guruvayoorappan et al., 2008; Zucker and Vacirca, 2004).

In recent years much attention has been focussed on the natural products derived from plants as a source for the discovery of novel cancer chemopreventive agents (Surh, 2003; Weng and Yen, 2012). Flavonoids are polyphenolic compounds that are found in fruits and vegetables (Nijveldt et al., 2001). Flavonoids are found to possess cardioprotective effects (Mink et al., 2007). Previous reports have demonstrated that dietary flavonoids inhibit the development of various human cancers, such as breast cancer (Bosetti et al., 2005) and colorectal cancer (Rossi et al., 2006).

Naringenin, a plant bioflavonoid is present in fruits like oranges, grape fruits and tomatoes. It has been reported to possess anti-estrogenic activity (Ruh et al., 1995) antioxidant (Cheng and Breen, 2000; Cavia-Saiz et al., 2010) hepatoprotective (Hermenean et al., 2014), anticancer (Borradaile et al., 1999; Manthey et al., 2001), antiinflammatory (Manthey et al., 2001) and hypolipi-demic properties (Mulvihill et al., 2010). Naringenin with its health benefits presents a potent therapeutic that could be further explored. The present study was undertaken to investigate the effect of naringenin on metastasis of prostate cancer cells by evaluating the expression of MMPs-2/-9 and ERK1/2.

\section{Materials and Methods}

\section{Reagents and antibodies}

Naringenin (Sigma Aldrich, USA) was dissolved in dimethyl sulfoxide (DMSO) to a stock concentration of $10 \mathrm{mM}$. The concentrations used in this study were 10 , $20,30,40$ and $50 \mu \mathrm{M}$. The controls were treated with the same amount of DMSO as used in the corresponding experiments. Antibodies of MMP-2, -9, GAPDH, and pERK $1 / 2$ were obtained from Epitomics Inc. (USA). All other reagents used in the study were purchased from Sigma-Aldrich (USA).

\section{Cell culture}

PC-3 and DU145 cells were purchased from SigmaAldrich (USA) and maintained in RPMI 1640 medium supplemented with $10 \%$ fetal bovine serum (FBS), 100 $\mathrm{U} / \mathrm{mL}$ penicillin and $100 \mathrm{mg} / \mathrm{mL}$ streptomycin at $37^{\circ} \mathrm{C}$ in a $5 \% \mathrm{CO}_{2}$ atmosphere.

\section{Cell viability assay}

The prostate cancer cells (PC-3 and DU145) were seeded in a 96-well titer plate $\left(5 \times 10^{3}\right.$ cells/well). After 24 hours incubation at $37^{\circ} \mathrm{C}$ in the presence of $5 \% \mathrm{CO}_{2}$, various concentrations of naringenin $(10-50 \mu \mathrm{M})$ were added and the cells were incubated for 72 hours at $37^{\circ}$ C. Cell growth was assessed by MTT colorimetric assay (Limtrakul et al., 2004). The cytotoxicity assessment was performed in triplicates.

\section{Measurement of ROS generation}

The levels of ROS generated on exposure to naringenin were assessed by flow cytometric analysis. After incubition with naringenin at different concentrations (10 or $50 \mu \mathrm{M}$ ), the cells (PC-3 and DU145) were harvested, washed with PBS and suspended in RPMI 1640 medium containing $10 \mu \mathrm{M}$ 5(6)-carboxy-2', $7^{\prime}$-dichlorofluorescein diacetate (DCFH-DA) at $37^{\circ} \mathrm{C}$ for $20 \mathrm{~min}$. After incubation, the cells were washed again with PBS and ROS generation was measured using flow cytometer (Becton-Dickinson, San Jose, CA, USA).

\section{Analysis of MMP-2 and -9 activities by gelatin zymography}

The activities of MMP-2/-9 were measured after exposure to naringenin $(10$ or $50 \mu \mathrm{M})$. PC-3 and DU145 cells were $\left(5 \times 10^{5}\right.$ cells/well) plated in 12-well tissue culture plates and incubated in serum-free RPMI 1640 medium with or without naringenin for 48 hours. The conditioned medium was then collected and used for gelatin zymography. The samples were subjected to electrophoresis in $10 \%$ SDS-polyacrylamide gel containing $0.1 \%$ gelatin at $100 \mathrm{~V}$ for 3 hours at $4^{\circ} \mathrm{C}$. After electrophoresis, the gels were rinsed with $2.5 \%$ Triton X-100 to remove SDS at $4^{\circ} \mathrm{C}$. The gels were incubated overnight in activation buffer $(40 \mathrm{mM}$ Tris- $\mathrm{HCl}, \mathrm{pH} 8.0,10 \mathrm{mM}$ $\mathrm{CaCl}_{2}, 0.02 \% \mathrm{NaN}_{3}$ ) at $37^{\circ} \mathrm{C}$ followed by staining with $0.5 \%$ Coomassie blue R-250 for $60 \mathrm{~min}$ and destained with destaining solution (20\% methanol, $10 \%$ acetic acid, $70 \% \mathrm{H}_{2} \mathrm{O}$ ) until the clear bands were visualized and the band density was quantified by using $\mathrm{NIH}$ ImageJ software (USA).

\section{Western blot analysis}

Western blot analysis for MMP-2/-9 expression was performed. PC-3 and DU145 cells incubated with naringenin $(10$ or $50 \mu \mathrm{M})$ for 48 hours were collected. The harvested cells were suspended in $50 \mathrm{mM}$ potassium phosphate buffer $(\mathrm{pH}$ 7.4) containing EDTA ( $2 \mathrm{mM}$ ) and $0.1 \%$ Triton $\mathrm{X}-100$. The cells were sonicated and the homogenates were centrifuged for $10 \mathrm{~min}$ at $13000 \times \mathrm{g}$. The total protein in the supernatant were extracted and separated by SDS-PAGE and transferred onto a polyvinylidene difluoride (PVDF) membrane (GE Healthcare, USA). The membranes were blocked with blocking solution (1\%BSA in Tris-buffered saline Tween 20 (TBST)) and then incubated overnight with primary antibodies for MMP-2, -9, GAPDH, p-ERK1/2. After hybridisation with the primary antibody, the 
membrane was washed thrice with TBST. The membrane was then incubated with secondary antibody for 1 hour and washed with TBST. The final detection was done using the chemiluminescence Western blotting reagents (Amersham Pharmacia Biotech, UK).

\section{Real-time PCR - MMP-2/-9}

DU145 and PC-3 cells ( 1 x $10^{6}$ cells/well) were incubated without and with naringenin $(10$ or $50 \mu \mathrm{M})$ for 24 hours. After treatment, the cells were harvested and total RNA was extracted from each treatment by using the Qiagen RNeasy mini kit (Qiagen Inc., Valencia, CA, USA) as previously described (Lu et al., 2010; Chiang et al., 2011). RNA samples were reverse-transcribed using primers for MMP-2 and -9. Primer sequences $\left(5^{\prime}\right.$ to $\left.3^{\prime}\right)$ for MMP-2 were CTTCCAAGTCTGGAGCGATGT (forward) and TACCGTCAAAGGGGTATCCAT (reverse). GGGACGCAGACATCGTCATC (forward) and TCGTCATCGTCGAAATGGGC (reverse) were the primers for MMP-9. Reverse transcription was performed using Omniscript reverse transcriptase using Taq PCR master mix kit (Qiagen Inc., USA). The PCR reaction was initiated by using $20 \mathrm{pmol}$ of primers. Initial denaturation at $94^{\circ} \mathrm{C}$ for 3 min was followed by 30 cycles at $94^{\circ} \mathrm{C}$ for $1 \mathrm{~min}, 60^{\circ} \mathrm{C}$ for $1 \mathrm{~min}$ and $72^{\circ} \mathrm{C}$ for $1 \mathrm{~min}$ and the final extension was at $72^{\circ} \mathrm{C}$ for $10 \mathrm{~min}$. The amplified PCR products were separated on $0.8 \%$ agarose gel. The gel was stained using ethidium bromide and the bands were visualised on a UV transilluminator and the band intensities were measured using Image $\mathrm{J}$ software (USA)

\section{In vitro migration assay}

PC-3 and DU145 cells were plated at a density of $3.0 \times$ $10^{5}$ cells in 6-well plates and grown for 24 hours, where the cells reach about $90 \%$ confluence. The cell monolayer was carefully disturbed by scrapping out a small portion with a sterile $10 \mu \mathrm{L}$ plastic pipette tip so as to create a scratch. Debris was removed from the culture. The scraped portion was noted and cell migration into the denuded areas was assessed using a phase contrast microscope after 24 hours treatment with naringenin at $(10$ or $50 \mu \mathrm{M})$. The cell migration rate was determined using the formula: migration rate $=$ (average wound distance - average no migration distance) / average wound distance $\times 100 \%$.

\section{Statistical analysis}

Data were expressed as mean \pm SD from at least three independent experiments. One-way analysis of variance (ANOVA) and Student's t-test were used for statistical analysis. A value of $p<0.05$ was considered statistically significant. The statistical analyses were performed using SPSS 10.0 software.

\section{Results}

The anti-proliferative effect of naringenin on prostate cancer cells (PC-3 and DU145) was assessed by MTT assay. With increasing concentration of naringenin, from 10 to $50 \mu \mathrm{M}$ (Figure 1), the cell survival percentage was found to decrease.

At $10 \mu \mathrm{M}$ the cell survival percentage was observed to be $88.4 \%$ in PC-3 cells and $81.6 \%$ in DU145 cells. On exposure to $50 \mu \mathrm{M}$ naringenin the survival percentage decreased almost 3-fold in PC-3 and DU145 cells. The highest concentration of naringenin was most effective in inhibiting survival of prostate cancer cells.

MMPs are crucial in cancer metastasis. They are involved in ECM degradation, which is required for cell invasion. The effect of naringenin on the expression and activation of MMPs namely, MMP-2 and -9 were investigated in this study. PC-3 and DU145 prostate cancer cells were exposed to various concentrations of naringenin $(10$ or $50 \mu \mathrm{M})$. As shown in Figure 2 the results of Western blotting revealed that naringenin treatment significantly decreased MMP-2 and -9 expression in a dose-dependent manner. GAPDH expression served as a loading control. Treatment with 10 and $50 \mu \mathrm{M}$ of naringenin for 48 hours showed that the relative MMP2 and -9 protein expression levels in PC-3 cells decreased. We also observed the similar expression pattern of MMP-2 and -9 in DU145 cells on naringenin treatment.

The enzyme activities of MMP-9 and -2 were observed to be markedly $(\mathrm{p}<0.05)$ reduced as analyzed by gelatin zymography (Figure 3). Reduction in the activities of MMPs was found to be dose dependent. Exposure to 50 $\mu \mathrm{M}$ naringenin evidenced multifold decrease in the activities of MMPs as compared to the control cells, which were not exposed to naringenin.

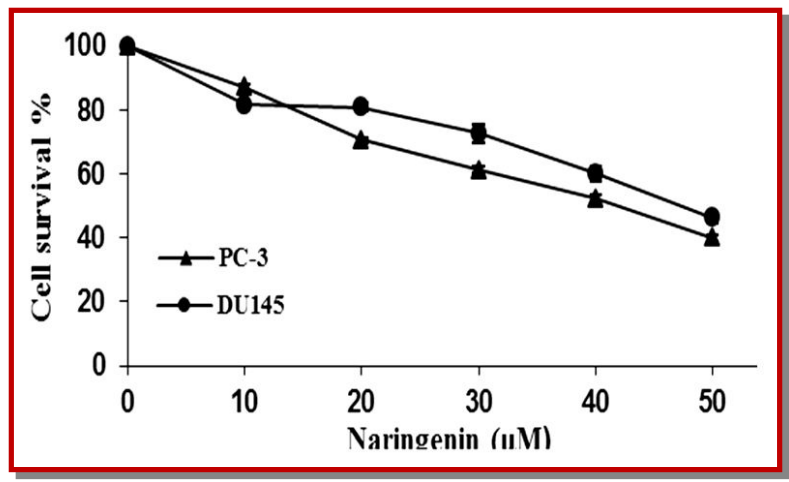

Figure 1: Effect of naringenin of cell viability of PC-3 and DU145 cells

Naringenin significantly inhibited cell growth of both cell lines in a dose dependent manner. The values are represented as mean \pm SD from three independent experiments 


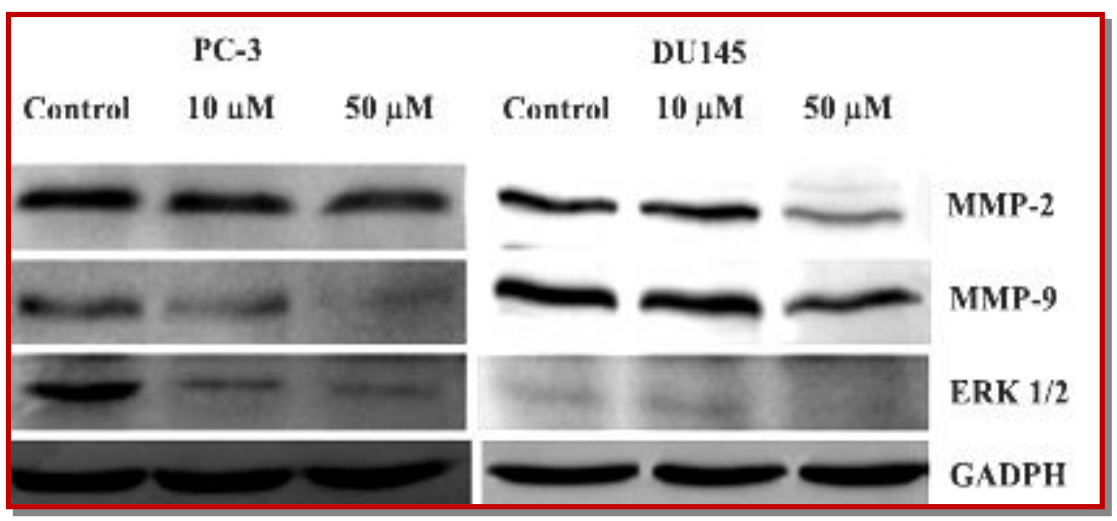

Figure 2: Effect of naringenin on MMP-2/-9 and ERK1/2 expression in PC-3 and DU145 cells determined by Western blotting. Naringenin was found to efficiently inhibit MMP-2/-9 and ERK $1 / 2$

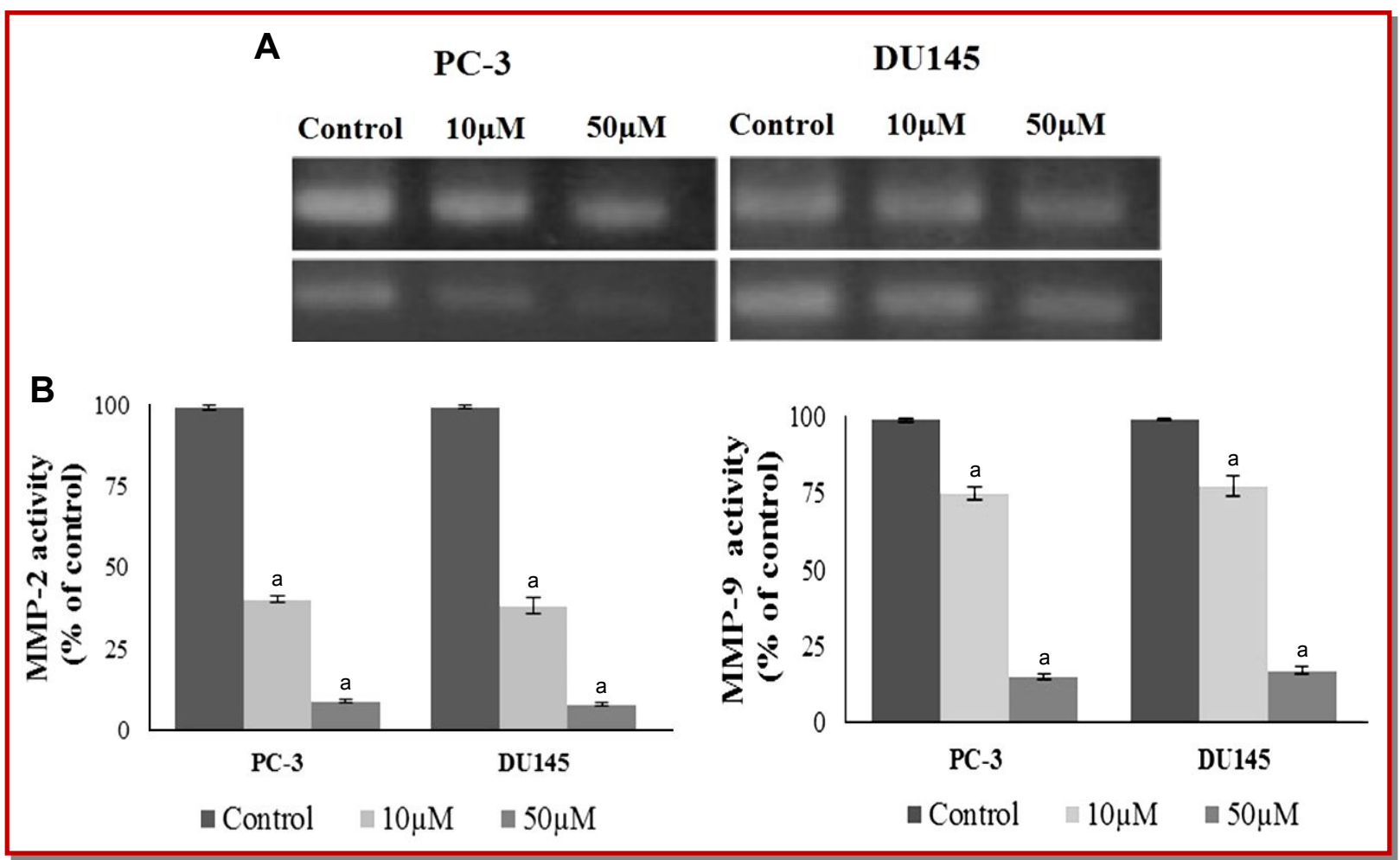

Figure 3: Effect of naringenin on the activities of MMP-2 and -9. (A) Gelatin zymography revealed the efficiency of naringenin in inhibiting the activities of MMP-2 and -9. (B) Inhibition percentage $(\mathrm{p}<0.05)$. Values are represented as mean \pm SD from three independent experiments

Expression of MMP-2 and -9 mRNAs was assessed by real-time PCR with GADPH as standard (Figure 4). The expression of MMP-2 mRNA dropped to $74.5 \%$ at 10 $\mu \mathrm{M}$ in PC-3 cells and $76.3 \%$ in DU145 cells as compared to untreated cells. Naringenin at $50 \mu \mathrm{M}$ was more effective in inhibiting mRNA expression of MMPs as evidenced in the study. The expression of MMP-2 mRNA dropped $36.1 \%$ in PC-3 cells and $31.1 \%$ in DU145 cells as against control.

These findings suggest that down-regulation of MMP-2 and -9 enzyme activities and expressions might be involved in the inhibition of invasion and migration of the prostate cancer cells.

The mitogen-activated protein kinase (MAPK) family are considered to be critical regulators of the various pathways that are involved in cell proliferation and migration (Roberts and Der, 2007). The effect of naringenin on ERK1/2 activation was measured by Western blotting (Figure 2). The results observed suggest that naringenin exposure inhibited ERK1/2, in a dosedependent manner in both PC-3 and DU145 cells, thus indicating that the decrease in the expression of MMP-2 and -9 could be via ERK1/2. 


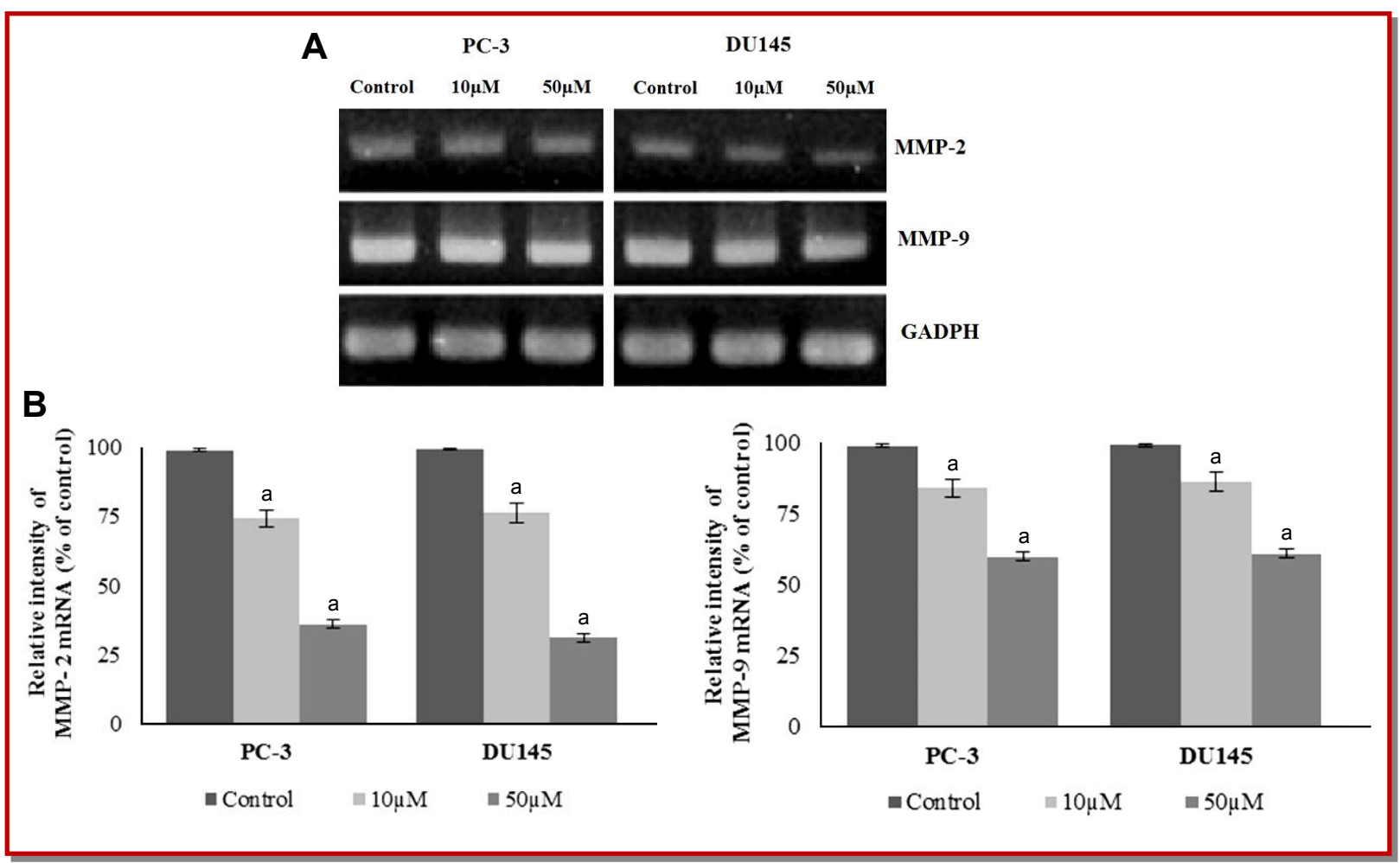

Figure 4: Influence of naringenin on MMP-2 and -9 mRNA expression. (A) Amplified real-time PCR product. (B) Relative intensity (\%) of MMP-2 and -9 mRNA. The values are represented as mean \pm SD from three independent experiments

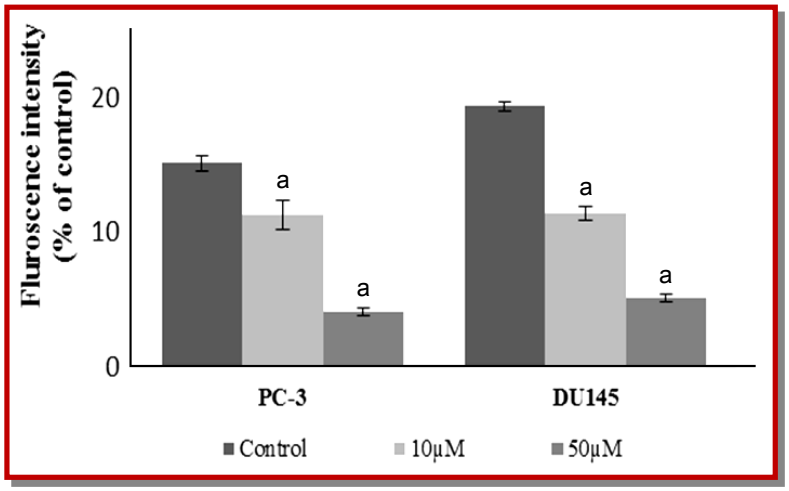

Figure 5: Effect of naringenin on ROS generation

Naringenin exposure was observed to decrease ROS production in both PC-3 and DU145. The values are represented as mean \pm SD from three independent experiments

The level of ROS generation was measured by flow cytometry. Cell-permeable dye DCFH-DA, which is specifically cleaved to emit a fluorescence wave length in the presence of ROS was employed. Treatment with naringenin suppressed the generation of ROS considerably in a dose-dependent manner, corresponding well to the phosphorylated ERK expression (Figure 5).

The effect of naringenin on migration of PC-3 and DU145 cells was studied by means of a wound closure assay. The cells were incubated with different concentrations of naringenin for 24 hours and the cell migra- tions were analysed. The result shown in Figure 6 suggests that naringenin suppressed migration of PC-3 and DU145 cells to the denuded zone in a dosedependent manner. The ratio of migration was reduced from 65.1 to $28.5 \%$ in PC-3 cells and from 64.4 to $25.2 \%$ in DU145 cells, respectively, when cells were incubated with naringenin at 10 and $50 \mu \mathrm{M}$ for a 24 hours treatment. These results revealed that naringenin was effectively inhibited the motility of PC-3 and DU145 cells in a dose-dependently.

\section{Discussion}

Metastasis and invasion are central characteristics of malignant cells. Proteolysis of ECM is important for cell protrusion. The proteolytic degradation of ECM, a major event in metastasis is mediated by extracellular proteases such as MMPs. MMPs play an important role in various pathologic processes such as angiogenesis and tumor invasion (Kahari and Saarialho-Kere, 1999; Chen et al., 2011). The chief MMPs that are involved in metastasis, MMP-2 and -9 play a crucial role in prostate cancer progression. The intensity of expression of MMP -2 and -9 is associated with the degree of prostate cancer progression (Stearns and Stearns, 1995; Nemeth, 2002). Thus, blocking tumor cell expression/inhibition of MMP-2/-9 could possibly suppress tumour invasion 


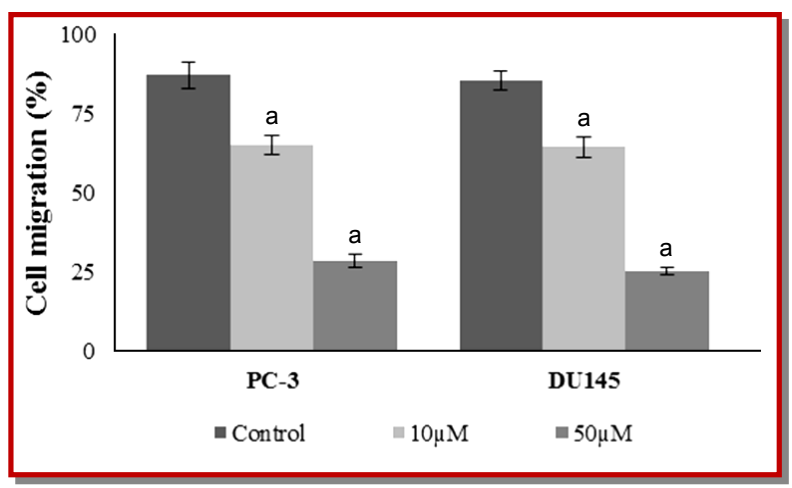

Figure 6: Effect of naringenin of cell migration of PC-3 and DU145 cells

Data are presented as mean \pm SD of three independent experiments

and metastasis of prostate cancer (Chien et al., 2010; Kong et al., 2007). Various plants and plant extracts have been explored widely in the treatment of cancer. Our study aimed to evaluate the efficiency of naringenin, a flavonoid on the expression of MMP-2/-9 in the metastasis of human prostate cancer cells, PC-3 and DU145 and the possible mechanism underlying the effect by evaluating the activation of ERK1/2.

The results of the cell viability analysis suggest that, naringenin at various concentrations on PC-3 and DU145 cells was able to effectively reduce the viability in a dose-dependent manner. The results suggest the anti-proliferative activity of naringenin. The migration of cells over the wound area was measured as indicative of the migratory capacity of the cancer cells. The marked decrease in the migration of the cells to the wounded area on exposure to naringenin suggests the efficacy of the compound in suppressing invasion of tumor.

The process of invasion and metastasis has been linked with the expression of MMPs. The expression and the activities of MMP-2 and -9 upon exposure to naringenin at 10 and $50 \mu \mathrm{M}$ for 48 hours suggests that naringenin significantly lowers the enzyme activities as evidenced by gelatin zymography. It is known that the activities of MMP-2 and -9 are involved in degradation of extracellular matrix and play important roles in cancer cell migration and invasion (Zhang et al., 2004; Bjornland et al., 2005). Our results demonstrated that antimetastastic effects of naringenin could possibly be associated with the inhibition of enzymatically degradative processes of metastasis in PC-3 and DU-145 cells. The results obtained were similar to Liu et al. (2011).

The levels of MMP-2 and -9 mRNA and the relative expression were analysed by RT-PCR and by Western blotting. In line with the results of the gelatin zymography, the expression patterns of MMP $-2 /-9$ and the mRNA levels were significantly reduced in the PC-3 and DU145 cells on naringenin exposure. Previous studies with phytochemicals, gallic acid (Liu et al., 2011) and magnolol (Hwang and Park, 2010) were found to effectively inhibit MMP-2 and -9 expression.

MAPKs have been implicated in regulating the proteolytic enzymes that degrade the ECM. Numerous studies have reported that the expression of MMPs- MMP-2 and -9 to be critically mediated by MAPK members and the AKT/ mTOR pathway (Kim et al., 2001; Shukla et al., 2007; Fang et al., 2013). MAPK pathways also play a vital role in tumor development and progression (Steelman et al., 2011). In metastatic cells the activity of ERK was observed to be higher than non-metastatic cancer cells. In tumors, the continued activation of MAPK could lead to enhanced induction of the proteolytic enzymes in the ECM, leading to the degradation which underlines a key event in metastasis and is a histological marker of invasive carcinoma. The role of ERK1/2 in cell invasiveness has been elucidated in many recent evidences. Our study investigated the influence of naringenin on ERK1/2 activation and also the possible role of ERK1/2 in modulating MMP-2 and -9 expression.

Naringenin at $50 \mu \mathrm{M}$ was found to inhibit ERK1/2 more effectively as compared to the lower concentration in PC-3 and DU145 cells. The observed results thus suggest that there might be a direct correlation between the activity of ERK1/2 and MMP -2 and -9 activities.

ROS are important signalling molecules that mediate a wide range of cellular responses, including apoptosis and metastasis (Lu et al., 2005). ROS have been shown to enhance ERK activity (Zhou et al., 2008). In the study, naringenin was observed to inhibit ROS levels thus suggesting the capacity of naringenin in counteracting ROS and thereby exhibiting the anti-oxidant efficacy. Previous reports have demonstrated the antioxidant capacities of various dietary flavonoids. Kaempferol has been shown to have diverse biological and pharmacological effects such as anti-oxidant activity and anticancer-related properties (Huang et al., 2014; Kang et al., 2010; Chen et al., 2013).

Kaempferol has been reported to reduce the expression of MMP-2 and -9 and inhibit ERK1/2 in cancer cells (Lin et al., 2013). Gallic acid was also reported to inhibit the levels of ERK1/2, the key molecules of the ERK signaling pathway that has been shown to promote tumor invasion and metastasis (Liu et al., 2011). Diosgenin, a naturally occurring steroidal saponin present in a variety of plants including fenugreek (Trigonella foenum graecum) and roots of wild yam (Dioscorea villosa) was observed to inhibit metastasis by inhibiting MMPs and ERK1/2 (Chen et al., 2011). 
Thus, the results of the study suggest that naringenin markedly suppresses the migratory ability of prostate cancer cells by suppressing the activities of MMP- 2/-9 and their expression. The possible mechanism of this suppression could be via reducing ROS levels and ERK1/2 activities. These observations imply that naringenin has a potent stand as a promising therapeutic drug in the treatment of prostate cancer.

\section{References}

Aimes RT, Quigley JP. Matrix metalloproteinase-2 is an interstitial collagenase. Inhibitor-free enzyme catalyzes the cleavage of collagen fibrils and soluble native type I collagen generating the specific 3/4- and 1/4-length fragments. J Biol Chem. 1995; 270: 5872-76.

Amaral TMS, Macedo D, Fernandes I, Costa L. Castrationresistant prostate cancer: Mechanisms, targets, and treatment. Prostate Cancer. 2012; 2012: 327253.

Bernhard EJ, Gruber SB, Muschel RJ. Direct evidence linking expression of matrix metalloproteinase 9 (92-kDa gelatinase/collagenase) to the metastatic phenotype in transformed rat embryo cells. Proc Natl Acad Sci USA. 1994; 91: 4293-97.

Bjornland K, Flatmark K, Pettersen S, Aaasen AO, Fodstad O, Maelandsmo GM. Matrix metalloproteinases participate in osteosarcoma invasion. J Surg Res. 2005; 127: 151-56.

Borradaile NM, Carroll KK, Kurowska EM. Regulation of HepG2 cell apolipoprotein B metabolism by the citrus fruit flavanones hesperetin and naringenin. Lipids 1999; 34: 59198.

Bosetti C, Spertini L, Parpinel M, Gnagnarella P, Lagiou P, Negri E, Franceschi S, Montella M, Peterson J, Dwyer J, Giacosa A, La Vecchia C. Flavonoids and breast cancer risk in Italy. Cancer Epidemiol Biomarkers Prev. 2005; 14: 805-08.

Cavia-Saiz M, Busto MD, Pilar-Izquierdo MC, Ortega N, Perez -Mateos M, Muñiz P. Anti-oxidant properties, radical scavenging activity and biomolecule protection capacity of flavonoid naringenin and its glycoside naringin: A comparative study. J Sci Food Agric. 2010; 90: 1238-44.

Chen PS, Shih YW, Huang HC, Cheng H-W. Diosgenin, a steroidal saponin, inhibits migration and invasion of human prostate cancer PC-3 cells by reducing matrix metalloproteinases expression. PLoS One. 2011; 6: e20164.

Chen HJ, Lin CM, Lee CY, Shih NC, Peng SF, Tsuzuki M, Amagaya S, Huang WW, Yang JS. Kaempferol suppresses cell metastasis via inhibition of the ERK-p38-JNK and AP-1 signaling pathways in U-2 OS human osteosarcoma cells. Oncol Rep. 2013; 30: 925-32.

Cheng F, Breen K. On the ability of four flavonoids, baicilein, luteolin, naringenin and quercetin, to suppress the fenton reaction of the iron ATP complex. BioMet. 2000; 13: 77-83.

Chiang JH, Yang JS, Ma CY, Yang MD, Huang HY, Hsia TC, Kuo HM, Wu PP, Lee TH, Chung JG. Danthron, an anthrax- quinone derivative, induces DNA damage and caspase cascades-medi-ated apoptosis in SNU-1 human gastric cancer cells through mitochondrial permeability transition pores and Bax-triggered pathways. Chem Res Toxicol. 2011; 24: $20-29$.

Chien CS, Shen KH, Huang JS, Ko SC, Shih YW. Antimetastatic potential of fisetin involves inactivation of the PI3K/Akt and JNK signaling pathways with down regulation of MMP $-2 /-9$ expressions in prostate cancer PC-3 cells. Mol Cell Biochem. 2010; 333: 169-80.

Emmert-Buck MR, Roth MJ, Zhuang Z, Campo E, Rozhin J, Sloane BF, Liotta LA, Stetler-Stevenson WG. Increased gelatinase A (MMP-2) and cathepsin B activity in invasive tumor regions of human colon cancer samples. Am J Pathol. 1994; 145: 1285-90.

Fang Z, Tang Y, Fang J, Zhou Z, Xing Z, Guo Z, Guo X, Wang W, Jiao W, Xu Z, Liu Z. Simvastatin inhibits renal cancer cell growth and metastasis via AKT/mTOR, ERK and JAK2/ STAT3 pathway. PLoS One. 2013; 8: e62823.

Feldman BJ, Feldman D. The development of androgenindependent prostate cancer. Nat Rev Cancer. 2001; 1: 34-45.

Gullu IH, Kurdoglu M, Akalin I. The relation of gelatinase (MMP-2 and -9) expression with distant site metastasis and tumour aggressiveness in colorectal cancer. $\mathrm{Br} \mathrm{J}$ Cancer. 2000; 82: 249 .

Guruvayoorappan C, Kuttan G. Amentoflavone inhibits experimental tumor metastasis through a regulatory mechanism involving MMP-2, MMP-9, prolyl hydroxylase, lysyl oxidase, VEGF, ERK-1, ERK-2, STAT-1, NM23 and cytokines in lung tissues of C57BL/6 mice. Immunopharmacol Immunotoxicol. 2008; 30: 711-27.

Hermenean A, Ardelean A, Stan M, Hadaruga N, Mihali CV, Costache M, Dinischiotu A. Anti-oxidant and hepatoprotective effects of naringenin and its $\beta$-cyclodextrin formulation in mice intoxicated with carbon tetrachloride: A comparative study. J Med Food. 2014; 17: 670-77.

Huang YB, Lin MW, Chao Y, Huang CT, Tsai YH, Wu PC. Anti -oxidant activity and attenuation of bladder hyperactivity by the flavonoid compound kaempferol. Int J Urol. 2014; 21: 94-98.

Hwang ES, Park KK. Magnolol suppresses metastasis via inhibition of invasion, migration, and matrix metalloproteinase-2/-9 activities in PC-3 human prostate carcinoma cells. Biosci Biotechnol Biochem. 2010; 74: 961-67.

Itoh Y, Nagase H. Matrix metalloproteinases in cancer. Essays Biochem. 2002; 38: 21-36.

Jemal A, Bray F, Center MM, Ferlay J, Ward E, Forman D. Global cancer statistics. CA Cancer J Clin. 2011; 61: 69-90.

Kahari V, Saarialho-Kere U. Matrix metalloproteinases and their inhibitors in tumour growth and invasion. Ann Med. 1999; 31: 34-45.

Kang JW, Kim JH, Song K, Kim SH, Yoon JH, Kim KS. Kaempferol and quercetin, components of Ginkgo biloba extract (EGb 761), induce caspase-3- dependent apoptosis in 
oral cavity cancer cells. Phytother Res. 2010; 24: S77-S82.

Kilian M, Gregor JI, Heukamp I, Hanel M, Ahlgrimm M, Schimke I, Kristiansen G, Ommer A, Walz MK, Jacobi CA, Wenger FA. Matrix metalloproteinase inhibitor RO 28-2653 decreases liver metastasis by reduction of MMP-2 and -9 concentration in BOP-induced ductal pancreatic cancer in Syrian Hamsters: Inhibition of matrix metalloproteinases in pancreatic cancer. Prostaglandins Leukot Essent Fatty Acids. 2006; 75: 429-34.

Kim D, Kim S, Koh H, Yoon SO, Chung AS, Cho KS, Chung J. Akt/PKB promotes cancer cell invasion via increased motility and metalloproteinase production. FASEB J. 2001; 15: 1953-62.

Kong D, Li Y, Wang Z, Banerjee S, Sarkar FH. Inhibition of angiogenesis and invasion by 3,3'-diindolylmethane ismediated by the nuclear factor-kappaB down-stream target genes MMP-9 and uPA that regulated bioavailability of vascular endothelial growth factor in prostate cancer. Cancer Res. 2007; 67: 3310-19.

Limtrakul P, Khantamat O, Pintha K. Inhibition of Pglycoprotein activity and reversal of cancer multidrug resistance by Momordica charantia extract. Cancer Chemother Pharmacol. 2004; 54: 525-30.

Lin CW, Chen PN, Chen MK, Yang WE, Yang CHTS, Hsieh YS. Kaempferol reduces matrix metalloproteinase-2 expression by down-regulating ERK1/2 and the activator protein-1 signaling pathways in oral cancer cells. PLoS One. 2013; 8: e80883.

Liu KC, Huang AC, Wu PP, Lin HY, Chueh FS, Yang JS, Lu CC, Chiang JH, Meng M, Chung JG. Gallic acid suppresses the migration and invasion of PC-3 human prostate cancer cells via inhibition of matrix metalloproteinase-2 and -9 signaling pathways. Oncol Rep. 2011; 26: 177-84.

Lu HR, Zhu H, Huang M, Chen Y, Cai YJ, Miao ZH, Zhang JS, Ding J. Reactive oxygen species elicit apoptosis by concurrently disrupting topoisomerase II and DNAdependent protein kinase. Mol Pharmacol. 2005; 68: 983-94.

Lu CC, Yang JS, Huang AC, Hsia TC, Chou ST, Kuo CL, Lu HF, Lee TH, Wood WG, Chung JG. Chrysophanol induces necrosis through the production of ROS and alteration of ATP levels in J5 human liver cancer cells. Mol Nutr Food Res. 2010; 54: 967-76.

Manthey JA, Guthrie N, Grohmann K. Biological properties of citrus flavonoids pertaining to cancer and inflammation. Curr Med Chem. 2001; 8: 135-53.

Mink PJ, Scrafford CG, Barraj LM, Harnack L, Hong CP, Nettleton JA, Jacobs DR Jr. Flavonoid intake and cardiovascular disease mortality: A prospective study in postmenopausal women. Am J Clin Nutr. 2007; 85: 895-909.

Mizutani K, Kofuji K, Shirouzu K. The significance of MMP-1 and MMP-2 in peritoneal disseminated metastasis of gastric cancer. Surg Today. 2000; 30: 614-21.

Mook OR, Frederiks WM, Van Noorden CJ. The role of gelatinases in colorectal cancer progression and metastasis.
Biochim Biophys Acta. 2004; 1705: 69-89.

Mulvihill EE, Assini JM, Sutherland BG, DiMattia AS, Khami M, Koppes JB, Sawyez CG, Whitman SC, Huff MW. Naringenin decreases progression of atherosclerosis by improving dyslipidemia in high-fat-fed low-density lipoprotein receptor-null mice. Arterioscler Thromb Vasc Biol. 2010; 30: 742-48.

Nemeth JA, Yousif R, Herzog M, Che M, Upadhyay J, Shekarriz B, Bhagat S, Mullins C, Fridman R, Cher ML. Matrix metalloproteinase activity, bone matrix turnover, and tumor cell proliferation in prostate cancer bone metastasis. J Natl Cancer Inst. 2002; 94: 17-25.

Nijveldt RJ, van Nood E, van Hoorn DE, Boelens PG, van Norren K, van Leeuwen PA. Flavonoids: A review of probable mechanisms of action and potential applications. Am J Clin Nutr. 2001; 74: 418-25.

Okada Y, Gonoji Y, Naka K, Tomita K, Nakanishi I, Iwata K, Yamashita K, Hayakawa T. Matrix metalloproteinase 9 (92kDa gelatinase/type IV collagenase) from HT 1080 human fibrosarcoma cells. Purification and activation of the precursor and enzymic properties. J Biol Chem. 1992; 267: 12 $-19$.

Roberts PJ, Der CJ. Targeting the Raf-MEK-ERK mitogenactivated protein kinase cascade for the treatment of cancer. Oncogene. 2007; 26: 3291-10.

Rossi M, Negri E, Talamini R, Bosetti C, Parpinel M, Gnagnarella P, Franceschi S, Dal Maso L, Montella M, Giacosa A, La Vecchia C. Flavonoids and colorectal cancer in Italy. Cancer Epidemiol Biomarkers Prev. 2006; 15: 155558

Ruh MF, Zacharewsky T, Connor K, Howell J, Chen I, Safe S. Naringenin: A weakly estrogenic bioflavonoid that exhibits antiestrogenic activity. Biochem Phamacol. 1995; 50: 1485-93.

Schor SL, Allen TD, Harrison CJ. Cell migration through three dimensional gels of native collagen fibres: Collagenolytic activity is not required for the migration of two permanent cell lines. J Cell Sci. 1980; 46: 171-86.

Shukla S, MacLennan GT, Hartman DJ, Fu P, Resnick MI, Gupta S. Activation of PI3K-Akt signaling pathway promotes prostate cancer cell invasion. Int J Cancer. 2007; 121: 1424-32.

Simpson-Haidaris P, Rybarczyk B. Tumors and fibrinogen. Ann NY Acad Sci. 2001; 936: 406-25.

Stearns M, Stearns ME. Evidence for increased activated metalloproteinase 2 (MMP-2a) expression associated with human prostate cancer progression. Oncol Res. 1995; 8: 6975 .

Steelman LS, Chappell WH, Abrams SL, Kempf RC, Long J, Laidler P, Mijatovic S, Maksimovic-Ivanic D, Stivala F, Mazzarino MC, Donia M, Fagone P, Malaponte G, Nicoletti F, Libra M, Milella M, Tafuri A, Bonati A, Bäsecke J, Cocco L, Evangelisti C, Martelli AM, Montalto G, Cervello M, McCubrey JA. Roles of the Raf/MEK/ERK and PI3K/ PTEN/Akt/mTOR pathways in controlling growth and 
sensitivity to therapy-implications for cancer and aging. Aging 2011; 3: 192.

Surh YJ. Cancer chemoprevention with dietary phytochemicals. Nat Rev Cancer. 2003; 3: 768-80.

Weng CJ, Yen GC. Flavonoids, a ubiquitous dietary phenolic subclass, exert extensive in vitro anti-invasive and in vivo antimetastatic activities. Cancer Metastasis Rev. 2012; 31: 323-51.

Zhang L, Shi J, Feng J, Klocker H, Lee C, Zhang J. Type
IVcollagenase (matrix metalloproteinase-2 and -9) in prostate cancer. Prostate Cancer Prostatic Dis. 2004; 7: 327-32.

Zhou J, Chen Y, Lang JY, Lu JJ, Ding J. Salvicine inactivates beta 1 integrin and inhibits adhesion of MDA-MB-435 cells to fibronectin via reactive oxygen species signaling. Mol Cancer Res. 2008; 6: 194-204.

Zucker S, Vacirca J. Role of matrix metalloproteinases (MMPs) in colorectal cancer. Cancer Metastasis Rev. 2004; 23: 101-17.

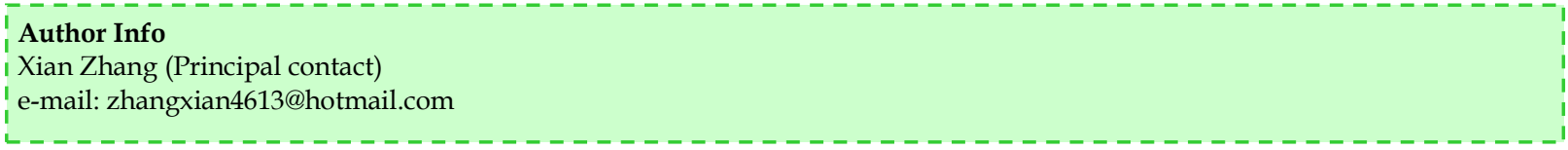

